\title{
Calling Cards: Ten Younger Irish Poets, Peter Fallon, Aifric Mac Aodha (eds.)
}

\section{Pádraic Lamb}

\section{(2) OpenEdition \\ 1 Journals}

Electronic version

URL: https://journals.openedition.org/etudesirlandaises/8998

DOI: 10.4000/etudesirlandaises.8998

ISSN: 2259-8863

Publisher

Presses universitaires de Caen

\section{Printed version}

Date of publication: 24 September 2020

Number of pages: 130-133

ISSN: 0183-973X

\section{Electronic reference}

Pádraic Lamb, "Calling Cards: Ten Younger Irish Poets, Peter Fallon, Aifric Mac Aodha (eds.)", Études irlandaises [Online], 45-1 | 2020, Online since 24 September 2020, connection on 14 November 2022. URL: http://journals.openedition.org/etudesirlandaises/8998; DOI: https://doi.org/10.4000/ etudesirlandaises.8998

\section{(c) (i) (2)(2)}

Creative Commons - Attribution-NonCommercial-ShareAlike 4.0 International - CC BY-NC-SA 4.0 https://creativecommons.org/licenses/by-nc-sa/4.0/ 
in recording everyday life and events of house and community: "Historically, diaries, particularly those of women, chronicled everyday life activities and events of the household and community - who was born, who got sick, who died, who got married, who visited, what was planted, what was made, and so on. Women played an important role in the social chronicling of family and community events". Remport's study highlights how ideas evident in Gregory's diaries were directly influenced by Ruskin and his ideas provided a solid philosophical underpinning to her own. A critical aspect to the book is how Remport notes the transition from art connoisseur to art critic, and from thinker to philosopher. In describing this change, the study succeeds very well in comparing Gregory's development with some of the social movements in Ireland with which she was connected in a period of accelerated social growth and political change.

In addition to its legacy on the intellectual, social and cultural life of the emerging Irish nation, the Revival still resonates in the material reality of modern Ireland, from its city streetscapes to its rural landscapes. Lady Gregory and Irish National Theatre: Art, Drama, Politics succeeds brilliantly in showing how Augusta Gregory's thinking was influenced by Ruskin, but also how it was distinct from that of both Ruskin and her friend and collaborator, W. B. Yeats. Given Remport's expertise in the visual arts and the consummate ease with which she employs her encyclopaedic knowledge of art history to support her thesis, a minor quibble might be that the monograph could have benefited from including plates from the visual artists whose tableaux vivants, sculptures and paintings were seminal for Ruskin, Gregory and their circle. Apart from that, this outstanding and extremely readable study enriches the body of research on Lady Gregory and the Revival, but it also opens the door for further research on the "sister arts" (p. 121) and the influence of contemporary thinkers and philosophers in Irish and English literary criticism and pedagogy.

Sorcha De BRÚN

\section{Calling Cards: Ten Younger Irish Poets, Peter Fallon, Aifric Mac Aodha (eds.), Loughcrew, The Gallery Press - Poetry Ireland / Éigse Éireann, 2018, 112 p.}

Nuala Ní Dhomhnaill once described the act of writing poetry in Irish as an act akin to placing a baby in a basket and setting it downstream, in the hope that it would find some "iníon Fharoinn", "Pharaoh's daughter" (trans. Paul Muldoon). Dual-language anthologies, and there is now a number of them, may tell us little about the state or size of the Irish-reading public but it does perhaps show that the English-reading public for poetry in Ireland, as well as English-language Irish poets, at least regard an Ghaeilge with benevolence and some interest. 
This anthology, edited by Aifric Mac Aodha and Peter Fallon, in a similar vein to Dermot Bolger's 1986 Bright Wave / An Tonn Gheal, aims to give a snapshot of today's poetic activity in Irish, from Kerry to Belfast. The result, happily, is diverse in perspective and realisation as the poets showcased are from rural and urban backgrounds, and speaking from youth or experience. Many aim to capture, then elevate or preserve, the everyday. Caitlín Nic Íomhair, like Sally Rooney in the contemporary novel, trains her gaze on the world of the university (p. 28):

\author{
Féach mo rua mhórtasach, teann as a torthúlacht \\ ag meallacadh go meallacach ar catwalk an arts block \\ is an dúdalaí údaí thall \\ céadbholadh a collaíochta á cheilt go maolchluasach \\ ón bhuachaill sin grunge agus a stánadh lom drúiseach. \\ Look at that redhead, proud in her bloom, \\ strutting her stuff down the arts block catwalk, \\ and the shrinking, studious primrose over there, \\ hiding the buds of her shy sensuality \\ from the grungy lad with his too-frank stare. (trans. Colette Bryce, p. 29)
}

Others, like Doireann Ní Ghríofa (p. 70) and Stiofán Ó hIfearnáin (p. 36), explore passions or heightened experiences through lyric characters. Ní Ghríofa makes Deirdre of the Sorrows, the famous tragic heroine of the Ulster cycle (and latterly of J. M. Synge's play) speak. The part of the story revisited, the condemnation of an unborn child and her mother, makes the ancient myth newly poignant in today's Ireland of the Scandals:

\author{
Lean raic rabhadh Chathbhaidh \\ nach mbeadh i ndán dom \\ ach an $t$-olc, \\ nach dtiocfadh díomsa ach an slad. \\ Havoc followed Cathbhadh's verdict, \\ my future nothing \\ but trouble, \\ nothing but ruin to come through me. (trans. Eiléan Ní Chuilleanáin, p. 71)
}

Indeed, juxtaposed lyric perspectives are one of the pleasures of such a crosssection of differing talents and minds. Not often will the famous Irish tragic figure, Deirdre of the Sorrows, have met Melusine, nor, on a lighter note, a woman of any hair colour strutting her stuff down the arts block catwalk.

The diversity already mentioned is also to be seen and heard in the dialects printed here. Lexical variety is something that written Hiberno-English can render, but some of the subtleties are beyond it, as everything down to the verb endings can pull the reader to a particular Irish-speaking region, proclaim a sense of place and also independence from the much-maligned state-sanctioned central standard, an Caighdeán Oifigiúil. Indeed, perhaps, as the poet-critic Eoghan Ó Tuairisc 
once predicted, the existence of a written standard has strengthened writing in the dialectal forms, as they vie and vibrate with and against an authoritative form.

The other authoritative form for the Irish-language poet is of course English. On the whole, there is a sense that these poets, some native speakers, some who learned Irish, write seemingly unburdened with the psychodrama around the choice of language that caused such existential crises and opened such creative veins for poets of previous generations, like the Irish-language poet Seán Ó Ríordáin (1916-1977) or the bilingual Eoghan Ó Tuairisc (1919-1982) or Michael Hartnett (1941-1999). Caitlín Nic Íomhair dots the poem cited above with English words and closes with the neologistic tmesis, "clástrafuckinfóibeach" (p. 28); it does not seem to pose her a problem. This is no doubt positive for the poets' health and for the breadth of lyric subjects in contemporary Irish-language verse, but some readers may feel that certain poems here sometimes struggle to attain the compelling urgency, the force of lyric as life-or-death, that some more complex approaches to language and the language question can bring.

As often with this type of venture, a stellar cast of English-language poets have stepped up to ford the river of translation in various remarkable ways. Especially worthy of note, I think, is Medbh McGuckian's translation of Marcus Mac Conghail's “Beirt Bhan Óga” (p. 68, literally, “Two Young Women”). It is a highly "visible translation", to adapt Lawrence Venuti's term (The Translator's Invisibility: A History of Translation, London, Routledge, 1995), a visibly hostile translation of a type I do not recall ever seeing before in a co-operative venture such as this one. McGuckian draws her title, "Silk Kimonos", from a line of Yeats's "In Memory of Eva Gore-Booth and Con Markievicz", in which the poet reflects harshly on the current state of the two women named (one seems "withered old and skeleton-gaunt") and harks back to the days of their youth, when the two were beautiful ("Two girls in silk kimonos, both / Beautiful, one a gazelle"). Mac Conghail's speaker is witness to a love-scene between two women on a "rothar a ngrá" (p. 68), "sex-mo-pede" (p. 69, literally, "bike of their love"):

\author{
Bailíonn bean an trasnáin léi \\ ar rothar a ngrá \\ is suímse trasna \\ óna cailín ar an traein \\ le go mbeinn cóngarach do m'éad. \\ The front seat driver \\ nips off on their sex-mo-pede \\ while I insert my frame parallel \\ to the gazelle boarding the train, \\ keeping my penis envy under wraps. (trans. Medbh McGuckian, p. 69)
}

The last line of the Irish could be translated more literally as "so that I would be close to my jealousy". Mac Conghail's is a poem of the male gaze but does not seem leering to me; it is also a solitary individual looking on at a loving couple. 
The translator has drawn out what she must feel is the unsaid of the original and created a fine but very different poem in English. Should we read it as a translation from Irish to English and, at the same time, a translation from a male perspective to a female one? I cannot help but feeling that Mac Conghail is paying for the sins of the poetic father, Yeats, and his rejection of the mature, accomplished and decided Gore-Booth sisters.

Poetry anthologies, as well as poetic translations, are designed to spark curiosity, debate and a good row if at all possible. Calling Cards is an attractive, affordable volume that considerably widens the audience for these young Irish-language poets. There is much that is captivating and will arouse curiosity here, and the publishers should be saluted for the enterprise. It is to be hoped that readers, like so many Pharaoh's daughters, follow the cue, pick up the calling cards of these ten poets and go on to pay them a visit, in poetry readings and happenings around the country and, above all, in their solo published collections.

Pádraic LAMB

\section{Patrick Lonergan, Irish Drama and Theatre Since 1950, London, Methuen Drama, 2019, 263 p.}

Patrick Lonergan's latest book offers a well-informed survey of Irish drama and theatre in both the Republic of Ireland and Northern Ireland, from the 1950s to the present. It looks at a wide range of plays, productions, and theatrical initiatives and provides its readers with valuable, up-to-date information on the latest developments of Irish theatre. The originality of Irish Drama and Theatre Since 1950 lies in its interest in broadening our conception and understanding of what constitutes Irish theatre. The book argues for a more comprehensive, capacious definition - especially one which would embrace the internationalisation of Irish theatre. The influence of foreign playwrights and directors on Irish dramatists and theatre practitioners, and the role played by international audiences on the reception of Irish plays are thus consistently emphasised. Suggestion is even made that Irish productions of non-Irish plays could be considered as an integral component of Irish theatre. The notorious staging of Tennessee Williams's The Rose Tattoo by the Pike Theatre Club in 1957 as part of the first Dublin Theatre Festival is here a case in point. Lonergan argues that the controversy generated by the showing of a (non)condom on stage at a time when contraception was illegal may be regarded not so much as symptomatic of "what was wrong in Ireland at the time", but as an "act of resistance" which proved instrumental to "the dismantlement of Irish censorship" (p. 52-53): the work of Pike's co-founders Carolyn Swift and Alan Simpson had a significant bearing on the subsequent developments of Irish theatre and society, especially as regards its secularisation. 